\title{
Teaching Engineering Design module from Engineering Exploration and Design Project (EEDP) course through hands on activities
}

\author{
Sachin B. Khot ${ }^{1}$, Prashant J. Jadhav ${ }^{2}$, Prakash M. Jadhav ${ }^{3}$ \\ ${ }^{1,2,3}$ Department of Mechanical Engineering, Rajarambapu Institute of Technology, Rajaramnagar, Sangli- 415414 \\ ${ }^{1}$ sachin.khot@ ritindia.edu, \\ ${ }^{2}$ prashant.jadhav@ritindia.edu, ${ }^{3}$ prakash.jadhav@ ritindia.edu
}

\begin{abstract}
This article highlights the experience of teaching Engineering Design module in Engineering Exploration and Design Project (EEDP) course through various handson activities. This multidisciplinary course is offered to the first-year engineering students from all engineering disciplines. In Engineering Design module, teaching Engineering Design process is the main and important topic which is the basis for any project. This process has five important steps which are taught through various hands-on activities designed by the author. This paper presents the application of the engineering design process by students through one activity. The rubric for assessment is discussed, and evaluation carried out is presented. The evaluation shows a good understanding of the process and needs for improvement in planning of the activity for the next session.

Keywords: Engineering Design, Engineering Exploration and Design Project, Hands-on activities, Engineering Design Process.
\end{abstract}

\section{Introduction}

Accreditation Board for Engineering and Technology (ABET) characterizes Engineering Design as it is the way of devising a system, component, or process to meet desired needs.. It is a decision making process (frequently iterative), in which the Engineering sciences and mathematics are applied to utilize resources optimally to meet an established objective. Among the central components of the structure procedure are the establishment of objectives and criteria, synthesis, analysis, construction, testing and evaluation (ABET).

\section{Corresponding Author}

Sachin B, Khot, Department of Mechanical Engineering, Rajarambapu Institute of Technology, Rajaramnagar, Sangli- 415414

Email: sachin.khot@ritindia.edu
Engineering Design Process is one of topic from Engineering Design module in EEDP course. EEDP course is mandatory for first year students from all engineering streams offered at RIT, Rajaramnagar, Sangli, India. Students in this course are provided with hands - on learning practice, wherein the students undergo activities with increasing difficulty one after the other and students keep on raising upon their preceding understanding as the activities offer an amplified depth in understanding the theories. With frequent challenges through activities in this course students dwell in themselves in identifying answers to a couple of real - world problems which in turn enhances self-confidence in them. The syllabus of this course intensely indorses active learning, collaborative learning, peer learning, self - assessment, etc, with an emphasis on learning by doing. This course also stresses a course project submission which comprises forming project timelines, collecting data, blending facts, relating approaches to originate up with answers for the problem statement and many others (Kittur and Kavale, 2016). Course project needs application of Engineering Design process by students in solving the selected problem.

Most of engineering student lack in application of this process for the project problem undertaken. It leads to ineffective and infeasible solutions. Thus, an attempt was made in clear understanding of Engineering design process through various hands-on learning activities. The rubric for was designed for the evaluation of the activities as shown in table 2. The details of activities conducted under this module are discussed and one Mega activity carried out for the implementation of Engineering Design Process is shared along with its evaluation.

\section{Background}

Solving design problems is often an iterative process: As the solution to a design problem evolves, you find yourself continually refining the design. While implementing the 
solution to a design problem, you may discover that the solution you've developed is unsafe, too expensive, or will not work (Khandani, 2000).

Thus, there is necessity of solving Engineering design problem using a systematic approach. According to Seyyed Khandani, there are five basic steps in any engineering design process as shown in Fig.1

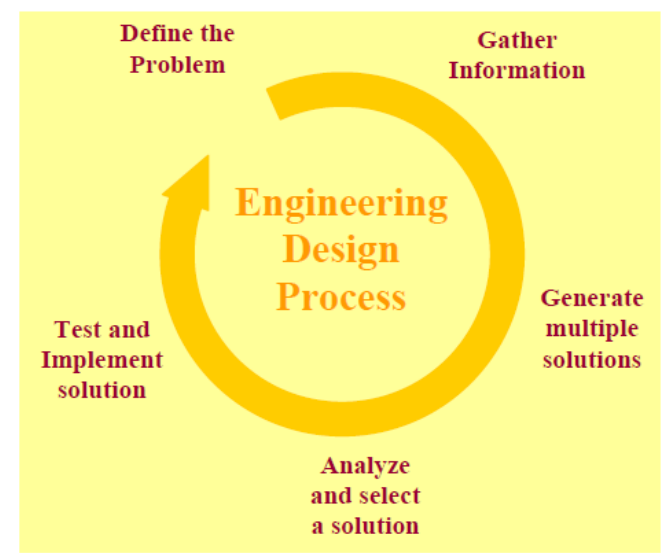

Fig. 1 Engineering Design Process

The first step in the design process is the problem definition. This definition typically covers a list of the product or customer wants and particularly information about product functions and features among other stuffs. In the next step, pertinent data for the design of the product and its functional specifications is achieved. A survey regarding the availability of like products in the marketplace should be made at this phase. Once the particulars of the design are evidently recognized, the design team with inputs from test, manufacturing, and marketing teams makes numerous alternatives to attain the goals and the necessities of the design. Seeing cost, safety, and other measures for selection, the more favourable alternatives are carefully chosen for additional investigation (Khandani, 2000).

Detail design and analysis step allows a complete study of the solutions and result in identification of the final design that best fits the product requirements. Following this step, a prototype of the design is constructed and functional tests are performed to verify and possibly modify the design. When solving a design problem, you may discover at any point in the process that you need to go back to a previous step. The solution you chose may prove unfeasible for any number of reasons and may require redefining the problem, collecting more information or producing different solutions (Khandani, 2000).

\section{Methodology}

All of these five phases of engineering design process are taught to students through various activities. The list of activities implemented for teaching each phase of Engineering design process is as shown in Table 1.

Table 1. Activities used for teaching Engineering Design Process Steps \begin{tabular}{|l|l|l|}
\hline Sr. & Engineering & Method Employed for teaching the \\
No. & Design & Process \\
\hline
\end{tabular}

\begin{tabular}{|c|c|c|}
\hline & Step & \\
\hline 1. & $\begin{array}{l}\text { Defining } \\
\text { Problem }\end{array}$ & $\begin{array}{l}\text { Case study based teaching- Case study } \\
\text { of Automobile Airbag Inflation - How } \\
\text { Not to Solve a Problem for teaching how } \\
\text { to initiate project with proper definition } \\
\text { of problem } \\
\text { Micro Activity for preparing problem } \\
\text { statement for design of a mousetrap }\end{array}$ \\
\hline 2. & $\begin{array}{l}\text { Collecting } \\
\text { Pertinent } \\
\text { Information }\end{array}$ & $\begin{array}{l}\text { Use of Internet for gathering pertinent } \\
\text { information }\end{array}$ \\
\hline 3. & $\begin{array}{l}\text { Generating } \\
\text { Multiple Solutions }\end{array}$ & $\begin{array}{l}\text { Random } \quad \text { word } \quad \text { Generations, } \\
\text { Brainstorming, Concept Mapping }\end{array}$ \\
\hline 4. & $\begin{array}{l}\text { Analysing and } \\
\text { Selecting the best } \\
\text { solution }\end{array}$ & $\begin{array}{l}\text { Use of Decision Matrix tool- for } \\
\text { selecting the best solution. } \\
\text { A real life problem of selecting the best } \\
\text { bike design among the available designs }\end{array}$ \\
\hline 5. & $\begin{array}{l}\text { Testing and } \\
\text { Implementation }\end{array}$ & $\begin{array}{l}\text { Project / task based learning: Mega } \\
\text { Activity: Bridge Building using Popsicle } \\
\text { sticks. }\end{array}$ \\
\hline
\end{tabular}

A case study on How not to solve problem of faulty airbags from Toyota motors was discussed with students for understanding of the first step. A situation of wrong interpretation of problem was discussed with students. Also, one micro activity was conducted to understand the process of generating the problem statement from the need statement. In this activity, students were asked to complete the template containing series of questions which resulted in a clear, unambiguous definition of the problem. For gathering pertinent information, author demonstrated authentic resources on the internet. Various tools like Random word generations, Brainstorming, Concept Mapping used for generating multiple solutions were discussed with students. Concept mapping tool was actually implemented with the exam of energy resources. For analysing and selecting the best solution generated through previous steps Decision matrix tool was used. A real life problem of selecting the best bike design among the selected alternatives was given to students. Finally, for implementing the engineering design process, a task was given to students of building the bridge. Student were supposed to implement all five steps of engineering design process in team of four to build a bridge using the popsicle sticks given to them within said timeframe. Testing criteria and method of calculation of score for the built bridge was also discussed with students.

\section{A. Implementation of Engineering Design Process: Bridge Building using Popsicle sticks.}

A group of four student was prepared for the activity. Objectives and constraints for the activity were discussed with the students. Testing and evaluation criteria was also explained to the students. Time limit of 60 mins was given to the students. Testing was carried out for $30 \mathrm{mins}$. And the inferences through the activity were discussed with the students.

The problem statement and testing criteria is as shown in Fig. 2. 
Student were asked to build a bridge using Popsicle sticks and a glue within 60 mins time frame. After bridge building,

Table 2. Rubric for evaluating the Engineering Design Module

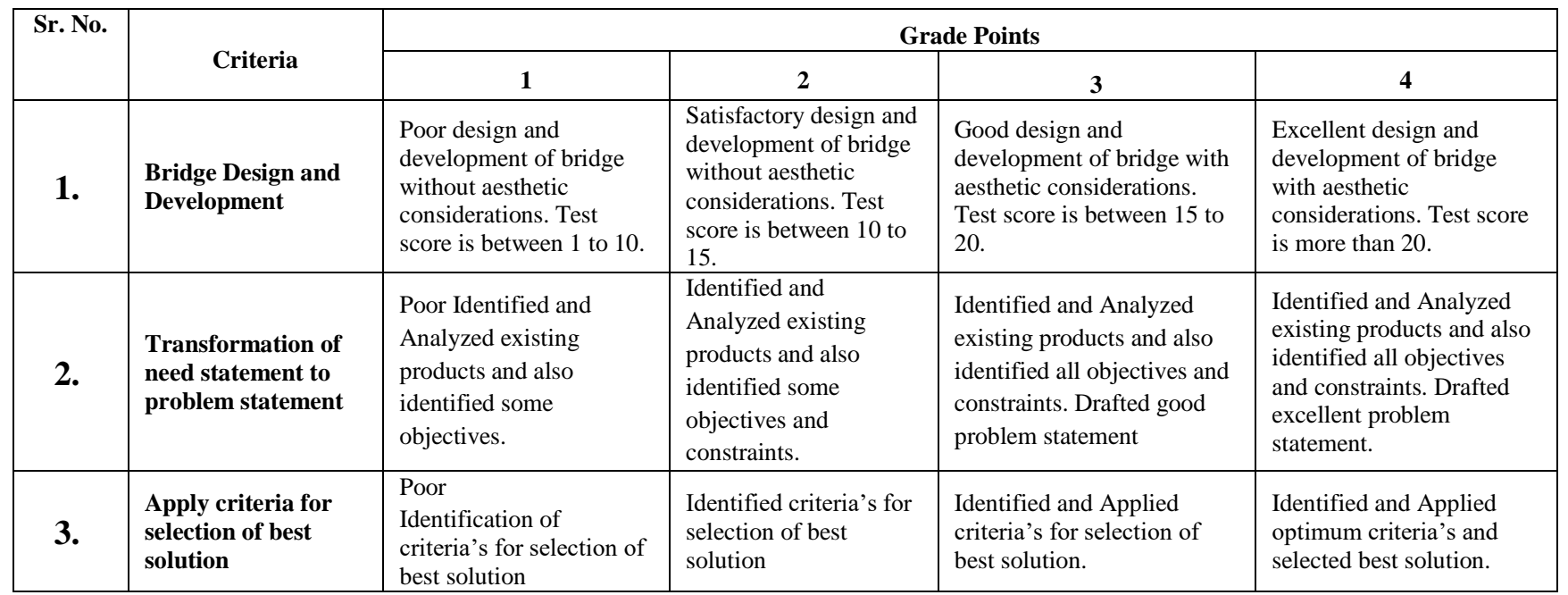

10 mins time was allowed for drying the glue and proper boding between the sticks. Sample bridge prepared by a group of student is as shown in Fig. 4.Then, each team were called in front for testing. Testing was carried out by

\section{Bridge building with Popsicle sticks}

Objective: Build a bridge made solely from Popsicle stick and glue which can hold $5 \mathrm{Kgs}$ of weight for 5 minutes.

-Prepare alternative designs and select the best design.

-Use Popsicle sticks to construct the bridge

-Test the design for the given constraints.

\section{Constraints:}

Not more than 100 sticks

Expecting to hold up to $5 \mathrm{Kg}$ of weight for 5 minutes.

\section{Testing Criteria and Method for calculating}

Score:

Score $=[(\text { Weight } * \text { time }) / \text { no. of sticks }]^{*} 100$

e.g.

Score $=[(5 * 5) / 100]^{*} 100=25($ Max. score $)$

Fig .2 Objective, Constraints and evaluation criteria of the activity.

\section{Implementation and Results}

EEDP course in one semester was offered to 4 divisions with 64 participants in each division and four teachers per class. The team of 4 students was prepared resulting 16 teams each. Identification number was allotted to each group as shown in table 3 . the instructors by applying the hanging weight at the centre of the bridge as shown in the Fig. 3.

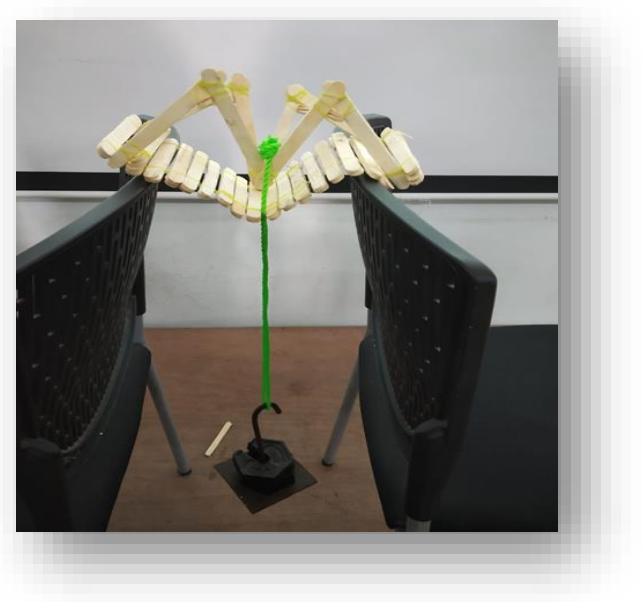

Fig. 3 Testing of the Popsicle stick bridge.

The Score of each team was calculated based on given formula which was written on whiteboard for comparing the results of each team. Results tabulated as shown in table 3.

Table 3. Score of each team

\begin{tabular}{|c|c|c|c|c|}
\hline $\begin{array}{c}\text { Group } \\
\text { No. }\end{array}$ & $\begin{array}{c}\text { No. of Sticks } \\
\text { Used }\end{array}$ & $\begin{array}{c}\text { Weight (in } \\
\text { Kg) }\end{array}$ & $\begin{array}{c}\text { Time (in } \\
\text { Min) }\end{array}$ & $\begin{array}{c}\text { Final } \\
\text { Score }\end{array}$ \\
\hline E01 & 45 & 4.5 & 2 & 20 \\
\hline E02 & 64 & 2 & 2 & 6.25 \\
\hline E03 & 30 & 1.7 & 2 & 11.33 \\
\hline E04 & 56 & 2 & 2 & 7.14 \\
\hline E05 & 80 & 1.4 & 2 & 3.5 \\
\hline E06 & 50 & 1 & 2 & 4 \\
\hline E07 & 80 & 2 & 2 & 5 \\
\hline
\end{tabular}




\begin{tabular}{|c|c|c|c|c|}
\hline E08 & 50 & 4.5 & 2 & 18 \\
\hline E09 & 58 & 2.5 & 2 & 8.6 \\
\hline E10 & 47 & 1.7 & 2 & 7.2 \\
\hline E11 & 33 & 0.7 & 2 & 4.2 \\
\hline E12 & 45 & 1.5 & 2 & 6.66 \\
\hline E13 & 45 & 1.5 & 2 & 6.66 \\
\hline E14 & 41 & 2 & 2 & 8.7 \\
\hline E15 & 51 & 1 & 2 & 3.92 \\
\hline E16 & 35 & 1.5 & 2 & 8.5 \\
\hline
\end{tabular}

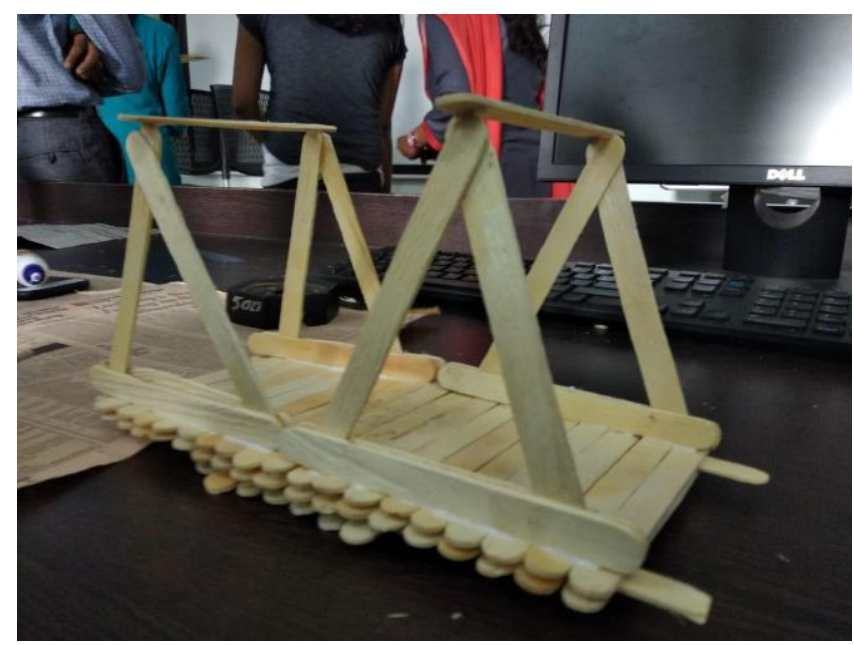

Fig. 4. Sample Bridge prepared by one group of students.

\section{Conclusions}

The attainment through rubric has clearly shown the active involvement of students in achieving the objectives that have been defined as the topic learning outcomes.

This activity originated good extent of group discussions amongst the teams and each participant was clarifying his view points to the other members of the team. Along with it there were some tangible outputs like student learnt to work in team with effective time management and effective use of resources. Some students have reported about insufficient time for carrying out the activity. Next time, some extra time can be allotted to the students for conducting the activity.

\section{References}

www.abet.org/accreditation/accreditation-criteria/criteriafor-accrediting-engineering-programs-2019-2020/

Javeed Kittur, Sanjeev M. Kavale, "Teaching Decision Making Method in Engineering Exploration Course - An Experience", Special Issue of National Conference NCIEME 2016 Organized by Rajarambapu Institute of Technology and Walchand College, Sangli ISSN 2394 1707

Seyyed Khandani, Engineering Design Process, August 2000, http://www.iisme.org/ETPExemplary.cfm 